\title{
FURNITURE AS FEATURE IN COWORKING SPACES. SPOTS IN PORTO CITY AS CASE STUDY
}

MUEBLES COMO CUENTA EN ESPACIOS DE COWORKING. LUGARES EN LA CIUDAD DE PORTO COMO CASO DE ESTUDIO

\author{
Rita Cruz* \\ Teresa Franqueira** \\ Fátima Pombo*** \\ Universidade de Aveiro \\ [ID+] Research Institute for Design
}

\begin{abstract}
In a few decades, the digital age came into our lives changing lifestyles and social behaviours, forcing the world to rethink daily experiences, including those taking place in the workplaces. The digital nomadism that facilitates the mobility and flexibility of work meets the requirements of today's society and stimulates the emergence of coworking spaces. Furniture design also needs to approach the new demands of current lifestyle. Within this context, the article intends to find out the role that furniture plays in such spaces. The research was carried out by studying a random sample of coworking spaces in Porto. An interview and a survey were conducted to the coworking space users in order to identify the furniture's common denominator in those places considering the pairs ergonomic function/comfort, materials/sustainability and flexibility/form as main parameters. The principal output of this study is to attract the attention of designers to the importance of furniture when considering the quality of coworking spaces in its multifunctional capacities in the context of a responsible, ecologic and sustainable society.

Keywords: Collaborative, Nomadism, Flexibility, Sustainability, Ergonomic, Covid-19

\section{Resumen}

En unas pocas décadas, la era digital llegó a nuestras vidas cambiando los estilos de vida y los comportamientos sociales, obligando al mundo a repensar las experiencias diarias, incluidas las que tienen lugar en los lugares de trabajo. El nomadismo digital que facilita la movilidad y flexibilidad del trabajo satisface las exigencias de la sociedad actual y estimula el surgimiento

\footnotetext{
*E-mail: ritamccruz@gmail.com

**E-mail: teresa.franqueira@ua.pt

***E-mail: fpombo@ua.pt
}

This work is financed by national funds through the FCT - Fundação para a Ciência e a Tecnologia, I.P., in the ambit of the project SFRH/BD/146306/2019.
\end{abstract}


de espacios de coworking. El diseño de muebles también necesita abordar las nuevas demandas del estilo de vida actual. En este contexto, el artículo pretende averiguar el papel que desempeñan los muebles en dichos espacios. La investigación se lleva a cabo mediante el estudio de una muestra aleatoria de espacios de coworking en Porto. Se realizó una entrevista y una encuesta a los usuarios del espacio de coworking con el fin de identificar el denominador común del mueble en aquellos lugares teniendo en cuenta la función ergonómica de los pares/ comodidad, materiales / sostenibilidad y flexibilidad / forma como parámetros principales. El principal resultado de este estudio es atraer la atención de los diseñadores sobre la importancia del mobiliario a la hora de considerar la calidad de los espacios de coworking en sus capacidades multifuncionales en el contexto de una sociedad responsable, ecológica y sostenible.

Palabras clave: Colaborativo, Nomadismo, Flexibilidad, Sostenibilidad, Ergonómico, Covid-19

\section{Introduction}

The effect of digital nomadism and the general fluidity of contemporary lifestyles is reflected in society's behaviour and routines, consequently it results in new ways of working. This reality facilitates the mobility and flexibility of work, meets the requirements of today's society and stimulates the emergence of coworking spaces (Kojo and Nenonen, 2014). ${ }^{1}$

Furniture design also needs to approach the new demands of current lifestyle to create work environments suited to this work paradigm. Why do people choose a coworking space to work? What is the impact of furniture in coworking spaces? What is the impact of covid-19 on coworking?

In this context, a special emphasis is given to the study of a random sample of coworking spaces in Porto city. Following literature review and previous research, a standard interview and a survey were created and applied to users to get information about the furniture's common denominator in those places considering the pairs ergonomic function/comfort, materials/sustainability and flexibility/form as main parameters.

This research intends to recognize furniture as a design feature in coworking spaces, in the improvement of the quality of work, and also to contribute to designers' awareness of placing furniture as core issue when considering the quality of coworking spaces in its multifunctional capacities in a context of a responsible, ecologic and sustainable society.

\section{New ways of work: Coworking}

Globalization, technological progress and demographic changes are megatrends that have the potential to change the nature of work, affecting the quantity and quality of available jobs, such as the way they are carried out (OECD, 2019). ${ }^{2}$ Already in 2001, Giddens highlighted the radical transformation of the essence of our daily experiences, that by changing the relationship between people and the functioning of institutions, it is necessary to create new 
work patterns with more flexible schemes for better professional performance and still maintain balance between family and work. ${ }^{3}$ As technology and culture evolve and the new virtual workspaces in society grow, so do lifestyles also change, including the ways we understand and live the meaning of work in our lives (O'Brien, 2011). ${ }^{4}$ Today the workplace is away from the conventional office concept, yet the need for physical work locations still exists, although in more flexible, versatile and mobile forms. Workplaces had to adapt to technological innovation, new devices and tools which influenced the working routines. If we think about the evolution of the desk since the 80's (fig.1) we realize that there was a drastic reduction in the number of objects that we need to work. The desk full of big objects as computer, books, phone, fax machine, journal, calendar, calculator, corkboard, globe, etc., is reduced to a laptop and a mobile phone with all functions of the old objects. The evolution of work objects reflects the lifestyles of society. In fact, "a collection of objects expresses the technological development of a human group, the ecological conditions it supports and the social relations system it practices". ${ }^{5}$

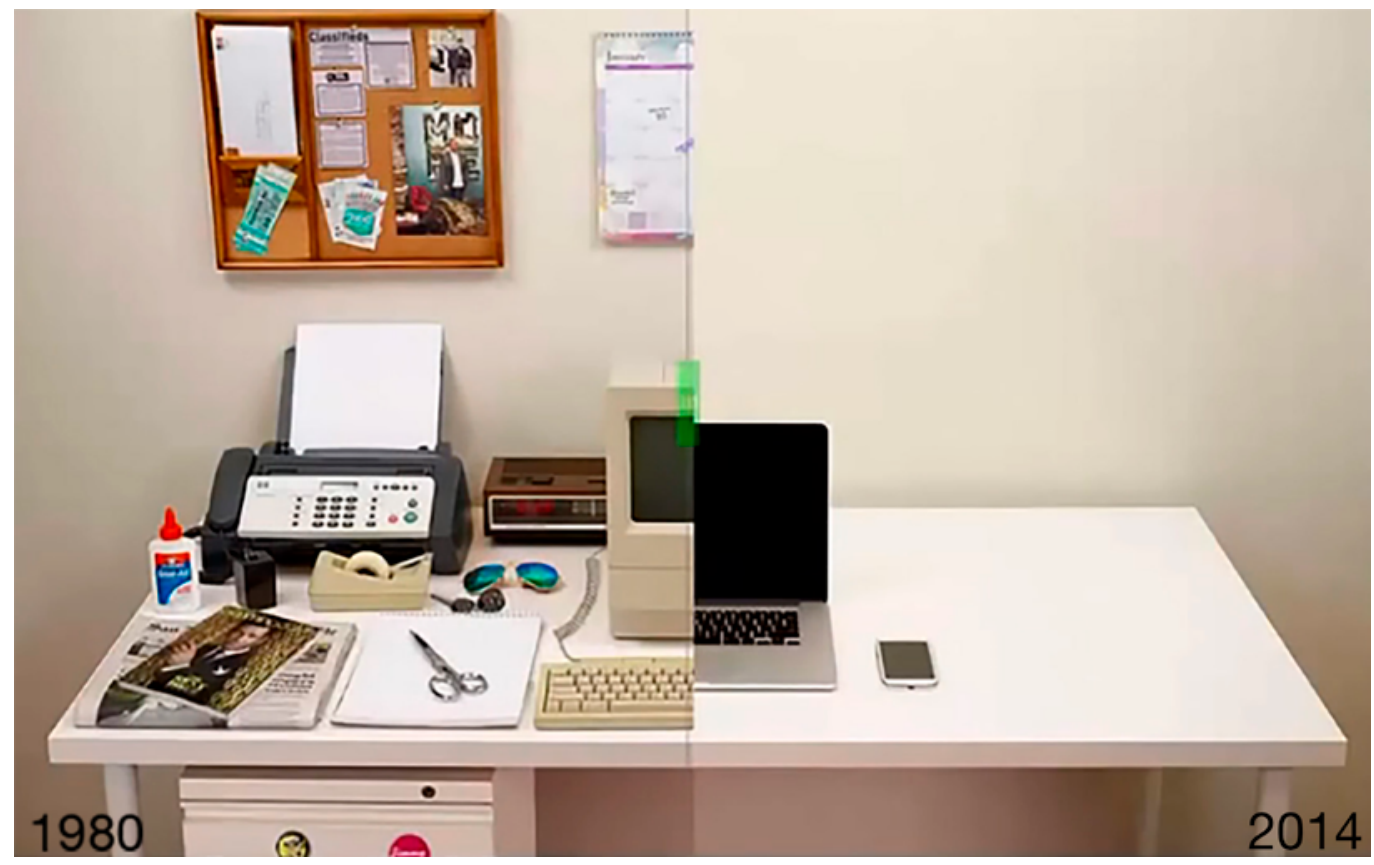

Fig. 1: The evolution of the desk by the Harvard innovation lab. Vimeo, accessed January 10, 2020, https://vimeo.com/107569286

Nowadays, the availability of digital devices enables the office to be anywhere: at home, at the cafe, in the library or even on travel as in trains, airplanes and airports. However, workers still seek workplaces that stimulate networking and collaboration potential. Reference companies such as Vitra, in which the CEO himself believes that technological evolution and demographic change are the main forces that transform our world of work, points out that "the office of today ought to support these new forms of work such as project work, spontaneous collaboration or mobile working and be an open space for innovation and creativity". ${ }^{6}$ 
The digital nomadism that facilitates the mobility and the flexibility of work meets the requirements of today's society and stimulates the emergence of coworking spaces. The number of freelancers who seek these spaces to escape the isolation of work at home or in individual offices is increasing. Coworking enhances the possibility to cooperate with other users from different areas of studies and professions. Job's market is changing, the number of entrepreneurs, startups and small businesses has been growing and consequently the demand for these coworking spaces. Millennials (generation $\mathrm{Y})^{7}$ who grew up within the digital technologies are also responsible for the demand of coworking spaces as places that promote and balance a professional performance with, among other facilities, break, conviviality, well-being, creativity, flexibility and cooperation. ${ }^{8}$

Coworking spaces are collaborative and sharing spaces that embrace these new ways of working, creating a flexible and collaborative environment and physical conditions that attract more and more professionals to work in these spaces.

\section{Motivations to work in a coworking space}

In the last decade, the popularity for coworking spaces has been increasing (Roth and Mirchandani, 2016 ${ }^{9}$; Coworking Resources, 2020 ${ }^{10}$ ). The major motivation for the growing demand of these workplaces was the combined result of two factors: 1) the technological evolution and digital nomadism that facilitates the mobility and the flexibility of work and 2) the awareness of the disadvantages of working in a classic office, at home, at the library or at the local café, such as the possible lack of social and professional interaction, isolation, and the blurred boundary between a private and a professional life. The coworking spaces combine the possibility of cooperation, networking, socializing and enhance creativity to various conditions and gains associated with a work spot. These diverse factors that highlight coworking spaces from other workplaces provide conditions that help improve productivity. The fact that it is a collaborative space, which allows interaction between the community of workers, promotes connections, networking and generating creativity. These sharing spaces also allow to escape from isolation and find a life and work balance, advantages that help in the organization and performance of daily tasks and consequently improves productivity and wellbeing.

The freelancers are the professionals who look most for these spaces to work, yet there is an increasing number of entrepreneurs, startups and small businesses who have been looking for them too. Digital nomads are also a group of professionals who have been growing and looking for coworking spaces to work temporarily in different locations all over the world, they are not confined to specific localities. Not only are these professionals able to work from wherever they please, but also they choose to pursue a life of perpetual movement, they work and travel at the same time and they do it simply by choice, to get to know new cultures and gain different experiences (Mouratidis, 2018) ${ }^{11}$. Millennials have a big interest in and concern about wellness, they value flexibility and control over how, when and where they work. This were the generation that enhance coworking spaces and promoted it as places healthier and happier to 
work, that balance a professional performance with cooperation, flexibility, and other amenities. However, more and more professionals from other generations are working in these spaces and recognize that wellness and wellbeing constitute an increasingly important factor in the workplace.

The factors most considered by coworkers when choosing a coworking space amongst others are: location and an ease of commuting, community, work environment, flexibility in times of access as also in modifying the contract, the type of desks available, amenities that are made available and budget. ${ }^{12,13}$ Thus, coworking spaces should emphasize these aspects to attract users and offer an ergonomic, health promoting and wellbeing working environment.

In the study that follows, it is also possible to identify the motivations that lead people to choose a coworking space to work and what conditions are more privileged to have in these workplaces.

\section{Methodology}

The investigation is carried out by studying 10 coworking spaces in Porto which is a city with remarkable examples in quantity and diversity of such spots. A standard interview and an online survey were prepared and applied to get information about the furniture's common denominator in those coworking spaces considering as main parameters the pairs ergonomic function/comfort, materials/sustainability and flexibility/form (fig.2). These parameters were determined according to the most evident needs reported during visits to coworking spaces and also by an analysis of the literature review. The ergonomic function associated with comfort is relevant to the well-being of coworkers. The flexibility related to the form of the furniture is indispensable to the dynamics of the community: collaboration, conviviality, networking, creativity, which require a great versatility of the space. Sustainability linked to the choice of materials and the life cycle of products, are also fundamental issues. For the purposes of this study, data were collected between April and July 2020, through a visit to the space and an informal interview with the founders, managers or person responsible for the coworking, in some cases by videoconference, and there was also an online survey of coworkers.

The coworking spaces were selected through a research on web about the most interesting coworking spaces in the city of Porto. In total, around 20 coworking spaces were contacted, but only 10 visits were done. Due to the covid-19 pandemic and the consequent lockdown, there was some difficulty in conducting the presential visits and therefore some interviews were made by videoconference and later, whenever possible, the presential visit was carried out with all hygiene and safety cares. Also due to the time limitation for doing this investigation combined with the restrictions created by the covid-19, there were some spaces that refused a visit and interview, either due to the lack of conditions in that timeline or because they had to close the spaces permanently. In order to understand the point of view of the coworkers, after the interview the heads of each space were asked to send by email the survey link to their coworkers. Unfortunately, only a total of 21 coworkers filled in the questionnaire. 
It is a small sample but the fact that most coworkers receive many requests to respond to surveys, leads them to ignore many of them.

The results of the interviews and the survey were analysed in a qualitative way by crossing the quantitative data of the survey with the data of the interview and the information obtained by observing the spaces during the visits.

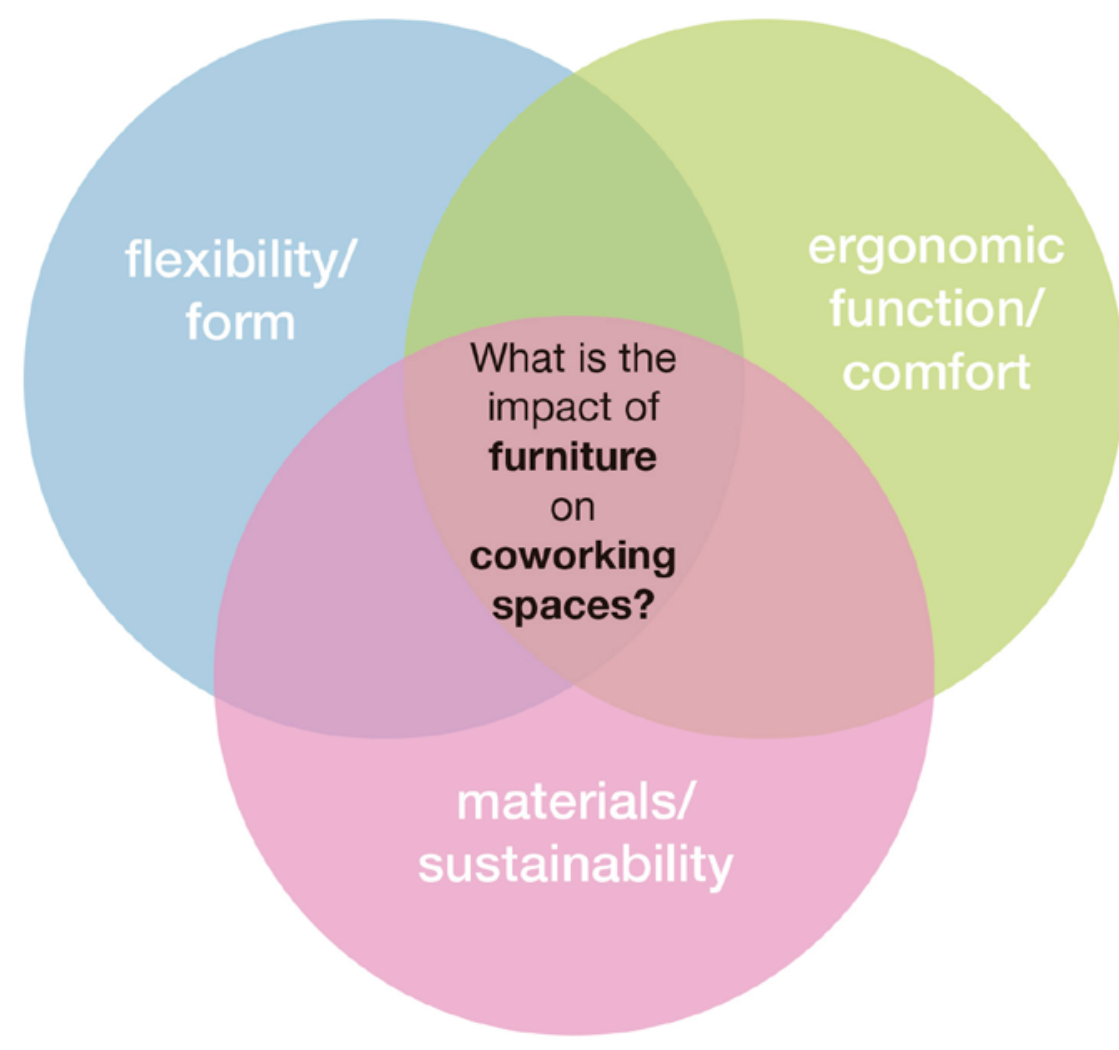

Fig. 2-Main question, considering as main parameters the pairs ergonomic function/comfort, materials/sustainability and flexibility/form.

\section{Coworking spaces in Porto city: Description, Analysis and Interpre- tation}

\subsection{Description}

A standard interview (table 1) shows the questions prepared and used during the visits and informal interviews to the 10 coworkings. From the data collected from the interview and from observation during the visit, forms were created in order to systematize the data and information obtained.

This information is described in next tables 2, 3, 4 and 5 according to the following criteria: general data of each coworking (table 2); available working areas for focus of each coworking (table 3); available conviviality areas for relax of each coworking (table 4); impact of the existing furniture in the coworking spaces considering as main parameters the pairs ergonomic function/comfort; materials/sustainability and flexibility/form (table 5). 


\section{Standard Interview | Guide}

Coworking space name:
Location:
Foundation Year:
Wounders / Managers:
Why was this space founded? How was it founded?
With mobile and digital technologies, today it is possible to work at home, in the
library, coffee.... What are the reasons that most lead coworkers to look for this
coworking space?
What do you consider from your experience the added value of being working in a
coworking space like this, compared to being at home? What do you consider to be
the strongest point of this coworking?

Generally the coworking spaces are sought by a young age people. Do you feel that this generation requires, in some way, better conditions in terms of available technologies, infrastructures and means of distraction?

Do you have startups or companies running? How many?

And what most motivates startups or companies to look for this coworking space?

Do you usually organize group activities and dynamics, even outside the work context? Which are? Do these dynamics help to create synergies between employees?

Was there a concern to give the space an identity? Did you take into account the identity and influence of the city of Porto?

Overall, do you consider the furniture in the different cowork spaces to be suitable?

What do you consider to be the impact of furniture on the organization of different coworking spaces?

Which area/ work space of the coworking is most sought/ frequented?

What influence did ergonomics and comfort have in the construction of this space or in the choice of these pieces of furniture?

Has the concern for sustainability influenced the choice of furniture pieces?

Regarding the acoustics, are there usually problems in some space? Is the existing furniture adequate to improve acoustic problems?

Is the furniture flexible enough to adapt the space to the different activities carried out on it? Would that be an asset to use the spaces?

Which piece/s of furniture do you think would improve the attractiveness of the space?

What do you think about the future of Coworking?

Table 1 - Standard Interview | Guide. 
Table 2 displays the general data of each coworking.

\begin{tabular}{|c|c|c|c|c|c|c|}
\hline & $\begin{array}{c}\text { Foundation } \\
\text { Year }\end{array}$ & Location & $\begin{array}{l}\text { Founders / } \\
\text { Managers }\end{array}$ & Occupation & $\begin{array}{l}\text { startups / } \\
\text { companies }\end{array}$ & Keywords \\
\hline 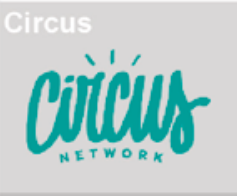 & 2015 & $\begin{array}{l}\text { Rua do } \\
\text { Rosário } \\
\text { | Porto }\end{array}$ & $\begin{array}{l}\text { André Carvalho } \\
\text { Ana Muska } \\
\text { (founders) }\end{array}$ & $\begin{array}{l}\text { capacity for } \\
\text { around } 12 \\
\text { people }\end{array}$ & & $\begin{array}{l}\text { Creativity } \\
\text { Synergies } \\
\text { Spontaneity } \\
\text { Collaborative } \\
\text { Art gallery }\end{array}$ \\
\hline $\begin{array}{l}\text { Facts } \\
\qquad \begin{array}{|l}\mid 5 \\
\text { ACTS COWORKING }\end{array}\end{array}$ & 2010 & $\begin{array}{l}\text { Boavista } \\
\text { | Porto }\end{array}$ & $\begin{array}{l}\text { Leo Lopes } \\
\text { (community mananger) }\end{array}$ & $\begin{array}{l}\text { capacity for } \\
\text { around } 40 \\
\text { people }\end{array}$ & & $\begin{array}{l}\text { Community } \\
\text { Collaborative } \\
\text { Tech ambience } \\
\text { Networking }\end{array}$ \\
\hline $\begin{array}{l}\text { Land } \\
\qquad \text { Lanc: }\end{array}$ & 2018 & $\begin{array}{l}\text { Rua do } \\
\text { Rosário } \\
\text { | Porto }\end{array}$ & $\begin{array}{l}\text { Mário Gomes } \\
\text { (founder) }\end{array}$ & $\begin{array}{l}\text { capacity for } \\
\text { around } 20 \\
\text { people }\end{array}$ & & $\begin{array}{l}\text { Identity } \\
\text { Nature } \\
\text { Networking } \\
\text { Design } \\
\text { Art gallery }\end{array}$ \\
\hline 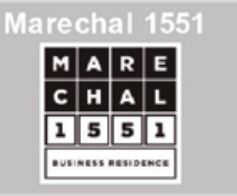 & 2017 & Foz|Porto & $\begin{array}{l}\text { Miguel Campos } \\
\text { (founder) }\end{array}$ & $\begin{array}{c}\text { capacity for } \\
\text { around } 30-35 \\
\text { people }\end{array}$ & & $\begin{array}{l}\text { Sophistication } \\
\text { Comfort } \\
\text { Cooperation } \\
\text { Sharing Economy } \\
\text { Prestige }\end{array}$ \\
\hline DFIIINA2 & 2013 & $\begin{array}{l}\text { Rua D. João IV } \\
\text { | Porto }\end{array}$ & $\begin{array}{l}\text { Vitor Rocha } \\
\text { Catarina Casanova } \\
\text { David Revez } \\
\text { (founders) }\end{array}$ & $\begin{array}{l}\text { capacity for } \\
\text { around } 20 \\
\text { people }\end{array}$ & & $\begin{array}{l}\text { Charismatic } \\
\text { Memory } \\
\text { Sharing } \\
\text { Identity } \\
\text { Architecture }\end{array}$ \\
\hline $\begin{array}{l}\text { Selina Navis } \\
\text { Selina } \\
\text { Navis cowork }\end{array}$ & 2018 & $\begin{array}{l}\text { Rua de José } \\
\text { Falcão| Porto }\end{array}$ & $\begin{array}{l}\text { Hugo Neves } \\
\text { (manager) }\end{array}$ & $\begin{array}{l}\text { capacity for } \\
\text { around } 90 \\
\text { people }\end{array}$ & & $\begin{array}{l}\text { Iconic building } \\
\text { Networking } \\
\text { Digital nomads } \\
\text { Community } \\
\text { Dynamic }\end{array}$ \\
\hline $\begin{array}{l}\text { Synergy } \\
\text { SWNERG }\end{array}$ & 2019 & $\begin{array}{l}\text { Av. de Fernão } \\
\text { de Magalhães } \\
\text { | Porto }\end{array}$ & $\begin{array}{c}\text { Inês Petiz } \\
\text { Hélder Vilares } \\
\text { (founders) }\end{array}$ & $\begin{array}{l}\text { capacity for } \\
\text { around } 20 \\
\text { people }\end{array}$ & & $\begin{array}{l}\text { Synergy } \\
\text { Flexibility } \\
\text { Proactivity } \\
\text { Creativity } \\
\text { Collaborative }\end{array}$ \\
\hline Temporada & 2018 & $\begin{array}{l}\text { Rua da } \\
\text { Torrinha } \\
\text { | Porto }\end{array}$ & $\begin{array}{l}\text { Vitor Miller } \\
\text { (founder) }\end{array}$ & $\begin{array}{l}\text { Variable. } \\
\text { No fixed } \\
\text { coworkers. }\end{array}$ & & $\begin{array}{l}\text { Flexibility } \\
\text { Identity } \\
\text { Modularity } \\
\text { Community } \\
\text { Coffee bar }\end{array}$ \\
\hline 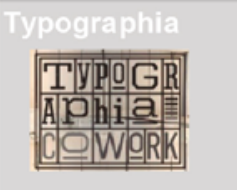 & 2016 & $\begin{array}{l}\text { Campo } \\
\text { Mártires da } \\
\text { Pátria | Porto }\end{array}$ & $\begin{array}{c}\text { Beatriz Silva } \\
\text { (commodity manager) }\end{array}$ & $\begin{array}{l}\text { capacity for } \\
\text { around } 22 \\
\text { people }\end{array}$ & & $\begin{array}{l}\text { Identity } \\
\text { Memory } \\
\text { Community } \\
\text { History } \\
\text { Collaborative }\end{array}$ \\
\hline by FINSA comp & 2018 & $\begin{array}{l}\text { Estrada da } \\
\text { Circunvalação } \\
\text { | Porto }\end{array}$ & $\begin{array}{l}\text { Ana Figueiredo } \\
\text { (commodity manager) }\end{array}$ & $\begin{array}{c}\text { capacity for } \\
\text { around } 40-45 \\
\text { people }\end{array}$ & & $\begin{array}{l}\text { Material gallery } \\
\text { Didactic } \\
\text { Flexibility } \\
\text { Dynamic } \\
\text { Networking }\end{array}$ \\
\hline
\end{tabular}

Table 2 - General data of each coworking. 
Table 3 shows the available working areas for focus of each coworking.

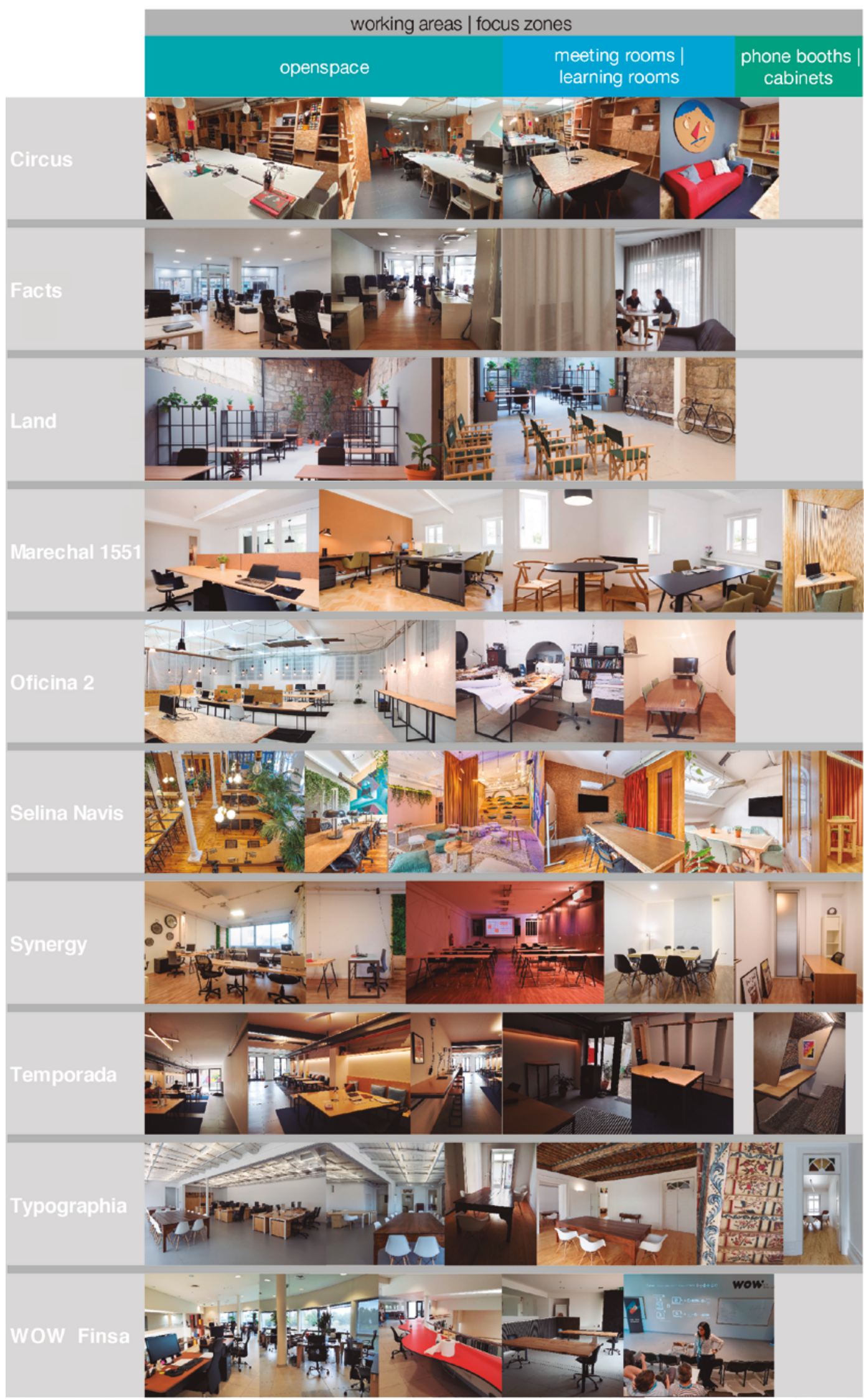

Table 3 - Available working areas of each coworking. 
Table 4 shows the available conviviality areas for relax of each coworking.

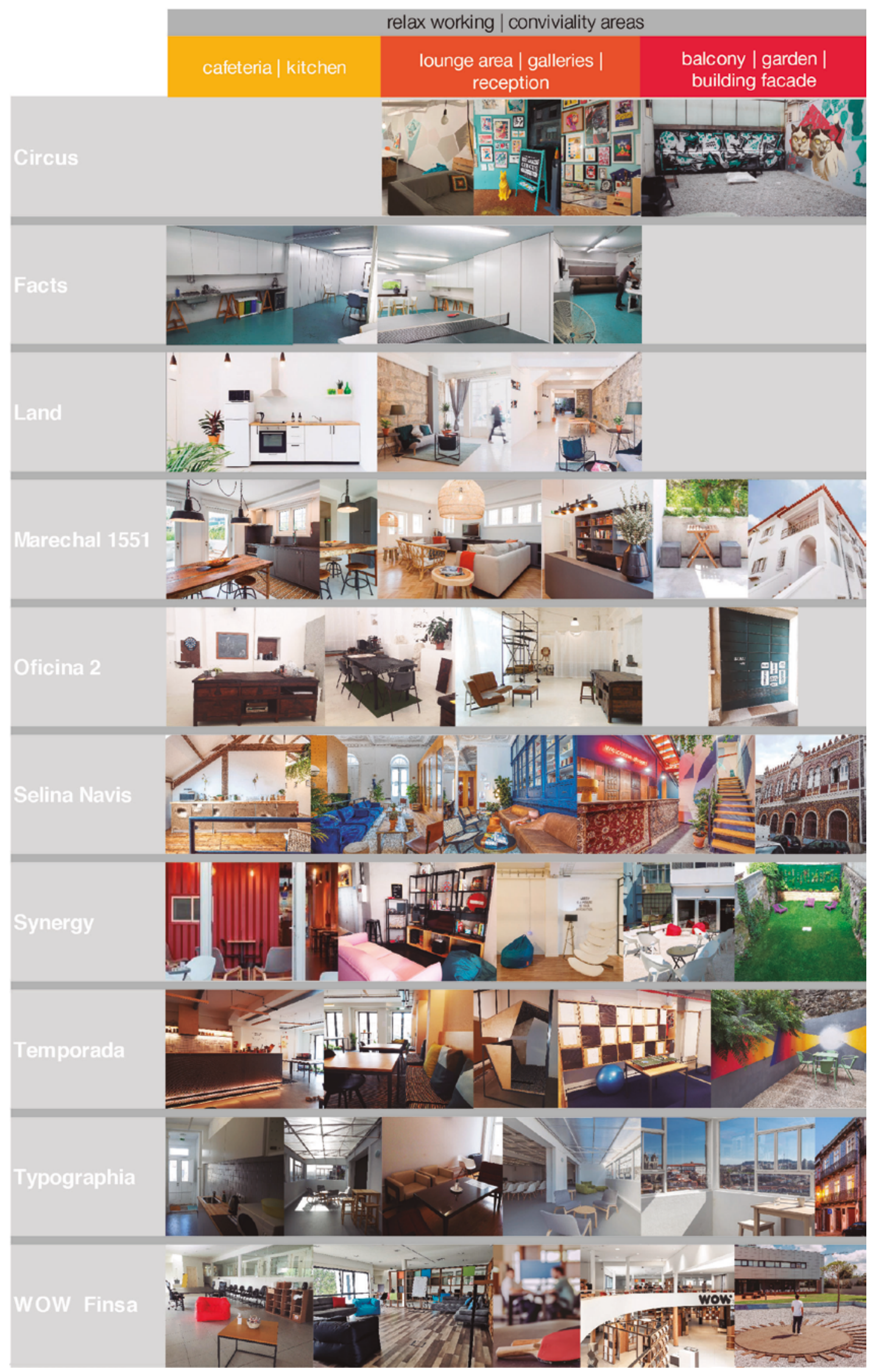

Table 4 - Available conviviality areas of each coworking. 
Table 5 depicts the impact of the existing furniture in the coworking spaces considering as main parameters the pairs ergonomic function/comfort, materials/sustainability and flexibility/form.

\begin{tabular}{|c|c|c|c|}
\hline & \multicolumn{3}{|c|}{ What is the impact of furniture on coworking spaces? } \\
\hline & flexibility/ form & materials/ sustainability & $\begin{array}{c}\text { ergonomic function/ } \\
\text { comfort }\end{array}$ \\
\hline Circus & $\begin{array}{l}\text { - stackable chairs } \\
\text { - easy desmountable } \\
\text { desks } \\
\text { - simplicity }\end{array}$ & - cheap materials & $\begin{array}{l}\text { - balanced layout } \\
\text { - connection with the art } \\
\text { gallery }\end{array}$ \\
\hline Facts & $\begin{array}{l}\cdot \text { easy desmountable } \\
\text { desks } \\
\text { - neutral furniture }\end{array}$ & - arquitectural details & - ergonomic chairs \\
\hline Land & $\begin{array}{l}\text { - tables with wheels } \\
\text { - easy desmountable } \\
\text { desks } \\
\text { - personality }\end{array}$ & - in some details & $\begin{array}{l}\text { - ergonomic chairs } \\
\text { - natural light }\end{array}$ \\
\hline Marechal 1551 & $\begin{array}{l}\text { - Flexible lighters } \\
\text { - Sophisticated design }\end{array}$ & $\begin{array}{l}\text { - some recyclable } \\
\text { materials }\end{array}$ & $\begin{array}{l}\text { - ergonomic chairs } \\
\text { - phone booth }\end{array}$ \\
\hline Oficina 2 & $\begin{array}{l}\text { - original furniture created } \\
\text { thinking about the } \\
\text { proposition use of space }\end{array}$ & $\begin{array}{l}\text { - furniture recovery } \\
\text { - Acustic Cork panels }\end{array}$ & $\begin{array}{l}\text { - workbenches for various } \\
\text { work positions (sitting and } \\
\text { standing) }\end{array}$ \\
\hline Selina Navis & $\begin{array}{l}\text { - some areas with furniture } \\
\text { and flexible layout }\end{array}$ & $\begin{array}{l}\text { - Recovered furniture: } \\
\text { tables, sofas. } \\
\text { - Woods reused for } \\
\text { structures and stairs. } \\
\text { - Energy efficiency. }\end{array}$ & $\begin{array}{l}\text { - ergonomic chairs } \\
\text { - balanced layout }\end{array}$ \\
\hline Synergy & $\begin{array}{l}\text { - stackable chairs } \\
\text { - easy desmountable } \\
\text { desks }\end{array}$ & $\begin{array}{l}\text { - some recyclable } \\
\text { materials }\end{array}$ & - lounge area for relaxation \\
\hline Temporada & $\begin{array}{l}\text { - Flexible and modular } \\
\text { furniture } \\
\text { - tables with wheels }\end{array}$ & $\begin{array}{l}\text { - some recyclable } \\
\text { materials }\end{array}$ & $\begin{array}{l}\text { - ergonomic chairs and } \\
\text { lighting } \\
\text { - balanced layout }\end{array}$ \\
\hline & - flexible cafeteria tables & - recovered work tables & - chairs from fixed places \\
\hline WOW Finsa & $\begin{array}{l}\text { - Furniture is very flexible, } \\
\text { the assembly of the desks } \\
\text { is done by inserts. } \\
\text { - flexible layout }\end{array}$ & $\begin{array}{l}\text { - The materials used are } \\
\text { from Finsa that has this } \\
\text { concern. }\end{array}$ & $\begin{array}{l}\text { - ergonomic chairs } \\
\text { - balanced layout } \\
\text { - furniture created with this } \\
\text { premise }\end{array}$ \\
\hline
\end{tabular}

Table 5 - The impact of the existing furniture in the coworking spaces. 
The results of the survey are shown in tables 6 and 7.

Table 6 depicts the user characteristics of the sample considering: age, gender, nationality and occupation. It means a large number of people with ages between 32 and 38 years old, from millennials generation. A large percentage of the coworkers with Portuguese nationality is related to the pandemic, because many digital nomads of other nationalities have returned to their countries.

\begin{tabular}{|c|c|c|}
\hline \multirow[b]{2}{*}{$\Delta a 0$} & \multicolumn{2}{|l|}{$\mathbf{N}^{\circ}$} \\
\hline & & \\
\hline $18-24$ & 2 & 9,5 \\
\hline $25-31$ & 2 & 9,5 \\
\hline $32-38$ & 13 & 61,9 \\
\hline $39-45$ & 3 & 14,3 \\
\hline $46-52$ & 0 & 0 \\
\hline $53-59$ & 0 & 0 \\
\hline $60-66$ & 1 & 4,8 \\
\hline Gender & & \\
\hline Female & 12 & 57,1 \\
\hline Male & 9 & 42,9 \\
\hline Nationality & & \\
\hline Portuguese & 19 & 90,7 \\
\hline Austrian & 1 & 4,8 \\
\hline Brazilian & 1 & 4,8 \\
\hline Occupation & & \\
\hline Designer & 4 & 19 \\
\hline Interior Designer & 1 & 4,8 \\
\hline Design student & 1 & 4,8 \\
\hline Architect & 1 & 4,8 \\
\hline Project manager & 2 & 9,5 \\
\hline Manager & 2 & 9,5 \\
\hline Sports Manager & 1 & 4,8 \\
\hline Consultant & 1 & 4,8 \\
\hline Administrative & 1 & 4,8 \\
\hline Digital Marketing / Advertising & 2 & 9,5 \\
\hline Teacher & 2 & 9,5 \\
\hline Lawyer & 2 & 9,5 \\
\hline Psicóloga & 1 & 4,8 \\
\hline Previous Workplace & & \\
\hline Home & 9 & 42,8 \\
\hline Company & 5 & 23,8 \\
\hline Cafeteria & 3 & 14,3 \\
\hline Library & 1 & 4,8 \\
\hline Office/ Studio & 2 & 9,5 \\
\hline Medical clinic & 1 & 4,8 \\
\hline
\end{tabular}

Table 6 - Sample characteristics $(\mathrm{N}=21)$. 
Table 7 shows the perception of coworker's about the space where they work, their main motivations and characteristics of the coworking's that most attract them to work.

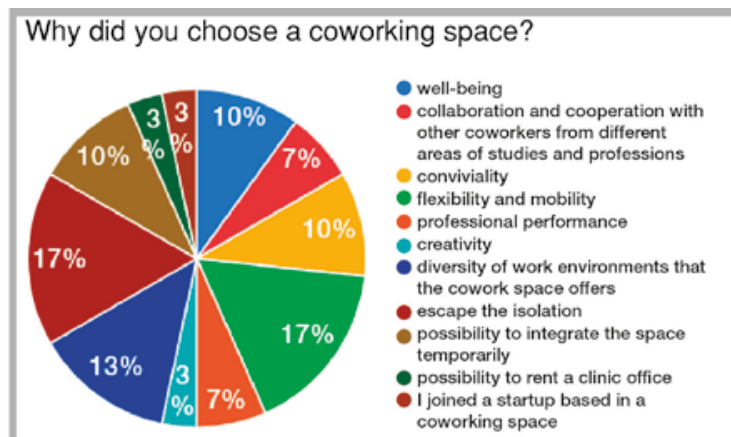

Which area of the coworking space do you use more?

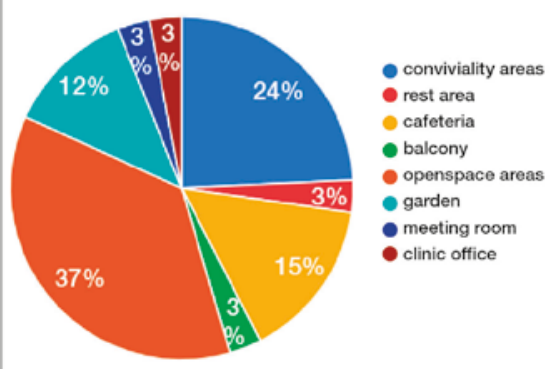

What kind of furniture with acoustic quality is there in the space?

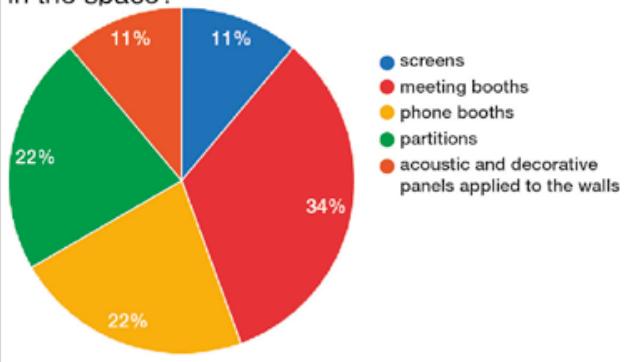

How important is furniture in coworking spaces?

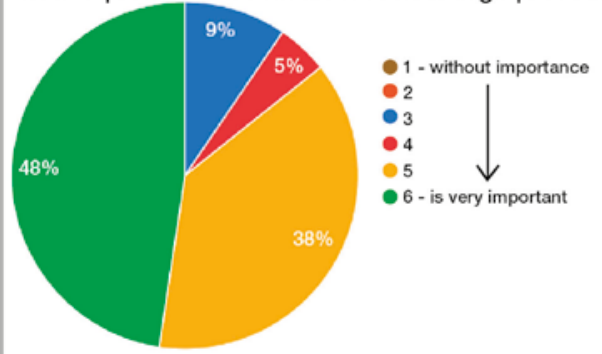

Is the furniture flexible enough to adapt the space to the different activities carried out on it?

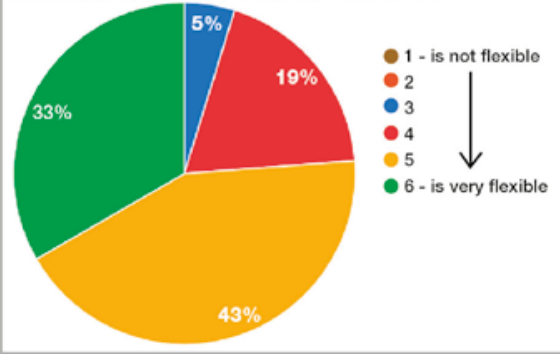

If you previously worked in another cowork space, what were the motivations that led you to move?

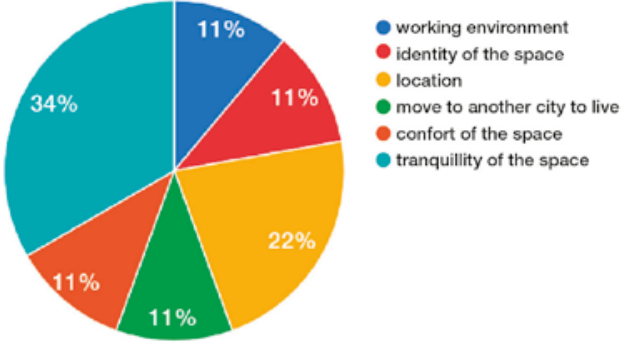

The acoustics of the space, noises of an openspace, are a problem for you?

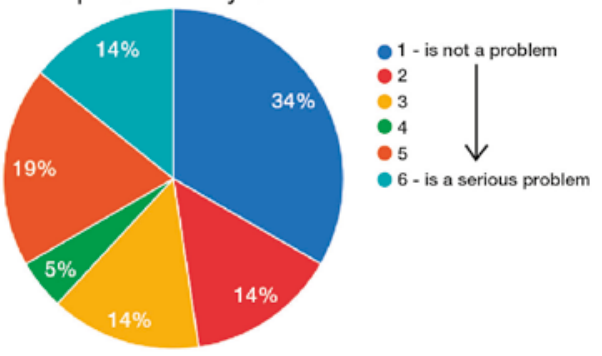

How do you focus in your task?
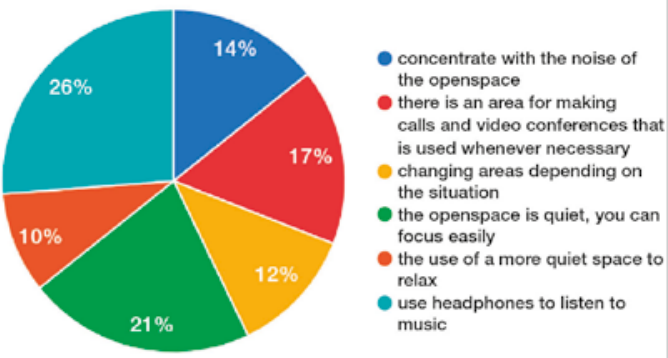

Why is furniture important in coworking spaces?

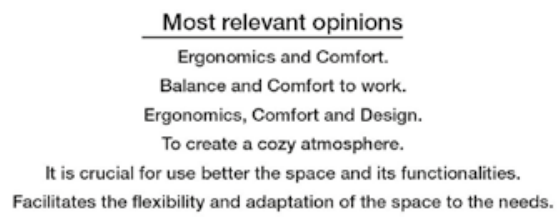

What would you change in terms of furniture in the space?

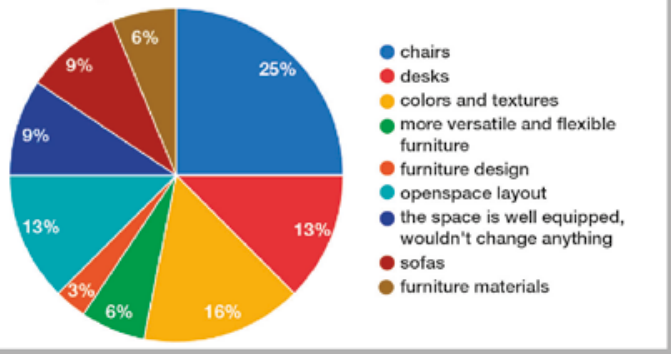

Table7-Survey results. 


\subsection{Analysis}

Based on the interviews the results are analysed for each coworking space.

Circus - Founded by artists with the aim of creating an art gallery that at the same time could cover a coworking space for share the space with other artists or from other creative areas. In addition to the coworking and art gallery there is a store integrated in the space. The strongest point of Circus, are the synergies and collaboration that arises between artists from different areas and the very relaxed, sharing and friendship environment that lives among the small community.

Facts - This coworking started out as a small sharing space in a smaller place in Boavista area and has evolved in order to be in a new larger space for two years. It is more oriented towards programmers, and its privileged location is an asset. Facts has a lounge area with video games and ping pong table that shows the tech ambience this coworking. When the space was visited, it was no longer the same as the original due to the pandemic, it had to go through changes in terms of layout and placement of acrylic screens as partitions to ensure all hygiene and safety standards.

Land - This coworking space, which has a strong identity, is divided into two areas: one more cultural for organizing exhibitions, events, workshops, which is the founder's work area, and another oriented to the coworking space. This space has the particularity of being open 24 hours a day with a gallery as a front office and is located in Rosário street in the city center, where there are many art galleries and other coworking spaces. The strong identity of the space is also reflected in the furniture that was made to measure for the Land with the exception of desk chairs that are ergonomic, but not exclusive. The furniture and space balance with plants and natural light convey the idea of being in the middle of nature.

Marechal 1551 - This is a completely different concept of the common coworking spaces, more sophisticated with high comfort areas. Located in a prestige area of Porto, in the Foz. Directed for people from this residence area, for an upper middle class. The coworkers are lawyers, psychologists, business people and people from diverse areas. The building of Marechal 1551 is an old family house. The design of the spaces and furniture is quite sophisticated, having the flexibility of a cowork space but maintaining the elegance and comfort of a prestigious hotel.

Oficina 2 - Located in a charismatic place of Porto, in the old factory complex of the centenary Cooperativa dos Pedreiros. Was founded by 3 architects with the idea of sharing the space with other people so they could help to pay the investment and bills and share interests and projects, creating partnerships. The character of the place is very strong and the idea was to maintain this identity, so that the spirit of the workshop and the factory remains. The furniture also reflects this identity, some countertops from the old workshop were recovered, it was almost all created by the architects. The reclamation of materials and experimentation were the major concern.

Selina Navis - In Porto, it is Selina's first space that is just for coworking without an integrated hotel. The proposal is more focused on companies 
and digital nomads with many associated activities to create more networking: yoga classes, talks, workshops, social events. The old and restored building is the hallmark of coworking. Selina Navis has that name because the proposal is very much geared towards Portuguese discoveries, the various meeting rooms are named after Portuguese discoverers, the floor and part of the original ceilings were maintained and is very similar to the hulls of boats. It is a space that combines antiquity with youthful spirit and its image serves both for a digital nomad and for more noble professions, a lawyer or a legal consultant.

Synergie - The space was founded because both founders were tired of working at home and wanted to create synergies and collaborations with other professionals. It started out as a café, with a workshop behind it for carrying out projects and ideas. Meanwhile coworking was being built from the workshop, most of the furniture and other pieces were built by the founder and other collaborators in the Synergy workshop. This coworking is directed for creative people and organize workshops and many different events for people from outside of the community, which improve the networking.

Temporada - This coworking has a very flexible concept, both in the form of use, as in the layout and furniture design. With a coffee shop as the entrance door, the coworkers can discount what they consume in the coffee shop and they can use temporarily the space for an hour or two without commitment. The space was designed so that anyone who passes by on the street feels free to enter and experience coworking. The identity of the furniture designed by the architect, guaranteed a position before other competitors and facilitated the communication of a concept. The flexibility and the modular component solved the space's profitability, allowing a single person to quickly change the space for a multiplicity of events and uses that may be necessary that were not even considered at the time the business plan was made.

Typographie - Coworking is located in the city center, next to Torre do Clérigos, in a building that housed an old typography. The building's identity has been maintained, with an openspace with a recovered typography tables, meeting rooms with beautiful old ceilings paintings, a lounge area with incredible panoramic view and a dining area, it manages to have an environmental informal and formal at the same time. With the pandemic they had to put acrylic screens because the old typography tables are not flexible to change the space configuration.

WOW - Work On Wood is a coworking space that was created by the company FINSA (solutions in wood) as a consequence of the search for a space for Finsa's sales people. The coworking idea came up, initially aimed for professionals in the area, but ended up opening up to other areas. The space has a didactic area with an exhibition of all materials and finishes on the lower floor, which makes the space interesting for professionals in the field of design and architecture. The didactic area has also digital tables, where professionals, students and anyone interested can see the available materials, learn about manufacturing processes, material specifications, certifications and even test how the finishes would look in a kitchen, floor, etc. The furniture was designed specifically for this space, uses materials exclusively from the end and is very 
flexible, the assembly of the desks is done by inserts, only the wave table for the most basic and temporary regime is fixed.

\subsection{Interpretation}

The pandemic was a challenge for all of these coworking spaces interviewed, both in terms of survival and the restructuring of the space for the return in compliance with all hygiene and safety standards. You can see that the coworking's with more modular and flexible furniture had an easier time adapting. All coworking founders or managers share the idea that coworking is the future of workspaces, which will increasingly be spaces planned for versatile demands of remote and collaborative work. Even with the pandemic, which is a difficult time for everyone, they believe that the coworking spaces that will survive the worst times will grow later. With the pandemic we learned how to work decentralized. So, in general they believe that cowork space will play a bigger role in the future. Freelancers and digital nomads will slowly begin to need to return to coworking to escape isolation and once companies realize that their workers do not have to be in the company office to be productive, they can choose to put workers at work in a coworking space, thus avoiding even some expenses.

In the analysis of the interviews, flexibility and modularity are highlight as essential for the good functioning of coworking spaces. In many of these spaces, cost is an obstacle to the acquisition of more versatile furniture and with an identity closer to the concept of space. Regarding the ergonomic function / comfort parameter, it is noticeable that the ergonomics and comfort of the chairs and the balanced layout were the main concern. Chairs are essential for well-being because coworkers spend a long time sitting on them working. In these coworking spaces is essential a balanced layout, that create functional paths and also allows people to cross each other in the right place and time to interact and collaborate. The flexibility / form parameter was the most weighted by all, and pointed with improvement potential.

Survey results (table 7) need to be interpreted with care, because of a relatively small sample size. When respondents were asked about why they chose a coworking space to work the most chosen reasons were: escape the isolation, flexibility and mobility, diversity of work environments that the cowork space offers, conviviality and wellbeing. And when asked about the motivation that led them to change of coworking space, if they have already worked in another one, the opinions are quite divided, although the tranquillity of the space and its location stand out. The most frequented areas of coworking are the openspace, followed by the conviviality areas, the cafeteria and the garden, so it is clear that the moments of concentration are divided into moments of conviviality and collaboration.

Regarding the acoustics of the spaces, we realize that for most of the coworkers it is not a problem, either because the spaces are quiet and there is mutual respect or because they have areas dedicated exclusively to making calls and videoconferences such as phonebooths and meeting rooms. And when they need to focus, usually they use phones for listening to music. 
Most coworkers believe that furniture is crucial to improving the quality of the space, being an important element in creating a comfortable, ergonomic space with a design suitable for the job. They consider that the furniture is sufficiently flexible and has a great contribution to the adaptation of the space to the different contexts that can be lived in a cowork, mainly in the organization of events and workshops. However, when questioning what they would change in the existing furniture, the chairs, desks, sofas and the colours and textures are pointed out, and there are still those who consider it should be more versatile and flexible.

The observation of such coworking spaces combined with information from the interviews and the survey, helps us to understand how the built environment can be used to help the flexible new ways of working and promote the collaboration and networking.

\section{Furniture as a design feature in coworking spaces}

Such as the definition of workplace is evolving and changing, also the working conditions offered in relation to physical and spatial composition related to the success in the work environment and wellbeing, are increasingly important factors to consider at the moment that coworkers choose the coworking where they want to work. The concept of coworking supports the idea of collaboration and sharing, so the spaces should convey the feeling a sense of belonging to the place and a feeling of comfort associated with a work environment that promote creative and professional performance. "Workplace as a physical space should offer productive and attractive spaces" (Makaklı, Yücesan\&Ozar, $2019)^{14}$.

In the line of Lipovetsky to keep up with contemporary nomadism, furniture design also needs to approach the new demands of current lifestyle. The lightness that referred to an idea of elegance, of aesthetic appreciation generally associated with art, now represents the performance of miniaturized, connected and portable objects that allow flexibility and mobility and simplify daily tasks (Lipovetsky, 2016) ${ }^{15}$. "The lightness of furniture (...) is part of a more global perspective, which brings into play the technical and industry, lifestyles, values, new ideas for the body and comfort" ${ }^{\prime 6}$. As referred by Pallasmaa (1996) ${ }^{17}$, multisensory experiences, the quality of the interiors, the materials and the scale are felt and are also measured by the eye, ear, nose, skin, tongue, skeleton and muscle. Rasmussen (1959) ${ }^{18}$ and Zumthor (2006) ${ }^{19}$ shows that sound depends on materials and shapes, and the diversity of possibilities for combinations between them, which creates different atmospheres. The way in which space is felt and the environment is experienced, varies with the material resources used, given that its influence on textures, reflection of light and propagation of sound are decisive. New materials, increasingly lighter, with specific properties (ergonomic, acoustic, well-being) and the forms they can acquire, are today fundamental for design. Miller (2018) ${ }^{20}$ stresses the importance of creating a healthy environment where companies, organizations and their employees can thrive.

In a recent 2019 study (Robelski, Keller, Harth and Mache) ${ }^{21}$, carried out with coworking spaces in Germany, the coworking space compared to the home 
office proved to be the preferred work arrangement not only in terms of job performance, social interaction and work environment, but also in terms of health and wellbeing aspects. As the aspects of the work environment, ergonomics and comfort were highlighted as fundamental characteristics to create satisfactory workplaces that promote health and wellbeing. The concern about health and wellbeing in the workplace is growing, the truth is the desirable level of comfort required for people to feel and work well is increasing. Designers and architects while designing an office environment, from the layout to the furniture, should address the more complex aspects of wellbeing such as satisfaction and social connectivity in order to be able to promote an engaged and productive worker. "While design alone cannot provide all the answers to promoting wellbeing, good design can create a supportive environment that actively facilitates best working practices, improved workflows, innovation and creativity, and reduced stress" 22 .

The world of work has definitely become more dynamic and social interaction with and a swivel office chair no longer matches these new ways of working. Therefore, there is a growing trend towards informal work areas and leisure areas to promote rest and conviviality, essential aspects to collective wellbeing, creativity and professional performance. Although coworking spaces always provide an individual desk or a place at a worktable, in general they already have or show the evidence to have areas with furniture that allow them to work or hold meetings more informally.

The emerging technology trends will be the support for mobile and agile working, allowing people flexibility and choice over where and when they work, and consequently it is an opportunity for designers to create new concepts taking into account new ways of designing and managing workplaces that are going to influence how we experience our workplaces. If, on the one hand, we will have more autonomy and facility to work from home, on the other hand the need to escape isolation and the hope of community and collaboration will lead people to move to the workplace. "Simply, technology creates the opportunity for multiple working spaces- home, office or in-between - and reduces the gap even further between people's professional and personal lives" ${ }^{23}$. The future of work involves a balance between the home office and workplace. Nicola Gillen (2019) believes that going to the office will be a more rarely and prized experience, but the "workplace will retain a place of collaboration and exchange, also providing many people with a place where they can belong". ${ }^{24}$ Therefore, the workplace should be more flexible, designed for moments of collaboration, interaction and socialization, because the focus and concentration of individual work will probably be more at home.

As it was revealed in the study at 10 coworkings of Porto city, it is necessary to further explore the modular and flexible furniture for models of informal and collaborative work, taking into account more sustainable materials that provide more comfort and the feeling of pleasantness. The design of the coworking's workplace should support, anticipate and propose new ways of working, namely through furniture adaptable to different contexts that facilitate the performance of this activity and brings the comfort of the workplace closer to the home space. 


\section{Coworking reality after Covid-19: The future of coworking?}

The impact of Covid-19 in the coworking spaces cannot be ignored. When this investigation started, in early of 2020 the virus wasn't a problem, but in the meantime, it has become crucial topic to every workplace, including coworking spaces. With the pandemic emerged sanitary measures, social distancing, increased hygiene, the use of masks and the rise of digital communication that facilitated and promoted the home office. This has not only changed the patterns of personal interaction but has also fundamentally altered the way we work.

Before covid-19 the number of coworking spaces worldwide was increasing ${ }^{25}$. What will be the impact of this pandemic on coworking spaces? In the months following the start of the pandemic crisis, several opinions were heard regarding the future of coworking. If in one hand some opinions suggested a potential drop in the coworking industry on the other hand others many companies and employees realized that remote work can be effective and this can actually benefit coworking ${ }^{26}$. In fact, in the beginning it was hard to survive for some coworking spaces, especially during the lockdown. But remote work is becoming more common. People who were forced to work remotely as a result of the pandemic have found it to be an overall positive experience that has effectively boosted productivity and it was also recognized by employers that remote work has largely been successful, allowing for business continuity. Based on this fact, coworking can become an extension of the corporate workplace (Jones, 2020). ${ }^{27}$ This way of working was already adopted by some companies, with the pandemic this reality can be extended. The fact that companies have realized that with remote work in general the efficiency of workers can be the same or higher, and that some expenses are reduced for both employers and employees, will be a motivation for companies to look forward to revise their work flexibility policies based on the success they experienced during the pandemic with a remote work and it can lead to the search for coworking spaces to receive workers from their companies. And the fact that there may be a considerable number of residents of city $\mathrm{X}$ who travel daily to work at the company in city $\mathrm{Y}$ can lead to the search for coworking spaces in city $\mathrm{X}$ by the employer to receive its workers. Or in some cases people who can work from home, but will need to escape isolation, probably will go looking for coworking spaces on your own.

With the pandemic and the serious crisis that the tourism sector is going through, many hotels have chosen to function as offices and coworking spaces. This concept of coworking in hotels in large urban centers was already promoted by some hotel chains before the pandemic. Now, it has being adopted by more hotels to face this crisis.

The fact is that the pandemic has led to lockdown, but people are slowly returning to workplaces. Therefore, companies and designers are working on solutions for a safe and productive return to the workplace. Also, the coworking spaces recognize immediately that distancing may be part of our new normal, and the concept of collaboration and connection remain more important than ever, so having a safe place to do that is essential. In accordance with all the safety and hygiene standards recommended and required by the health authorities, coworking spaces have been adapted to ensure that members can continue 
to work in a safe and healthy work environment. The return to the physical office requires certain measures in the design of workspaces and furnishings to protect people and prevent the further spread of the pandemic. Covid-19 has influenced the design of workplaces. Firstly, forced to create immediate solutions with screens and partitions and to reorganize the layouts with the existing furniture in order to guarantee the safety distance between people. Secondly, in the development of new furniture projects that respond to the new demands imposed by the pandemic, not only for the security required but also for the new forms of work adopted. The furniture design has now here an important responsibility, it has a new challenge: create furniture that solves the problems that workplaces faced to adapt to new measures, social distancing and hygiene habits, while maintaining the concept of collaboration required by cowork spaces. Designers have here an opportunity to create and developed furniture solutions with the following requirements: with materials easy to clean and resistant to cleaning and disinfection products, design furniture that allow to create layouts in order to maintain the safety distance between workers and transit zones, whenever possible and necessary screens and room dividers should be projected to protect individual users, to create teamwork spots with all hygiene and safety conditions for when the individual work is not feasible for certain work tasks and also create work spots for video call meetings, which will be more frequent. The fact is that all coworkings visited in the city of Porto during this investigation reflected changes in layout, furniture configuration, or implementation of acrylic screens, in addition to the necessary hygiene and safety measures.

\section{Final Remarks}

This investigation offered new insights into the preferences regarding the furniture used in coworking spaces and shows which gaps designers need to study and solve.

The relevance of furniture design in coworking spaces is transversal to the pairs ergonomic function/comfort, materials/sustainability and flexibility/ form considered in the study, as main parameters. The balance between these three pairs of parameters is essential to create the connections between the different moments of work: collaboration, learning, socialization, networking and individual focus. This balance is the main opportunity to be taken in furniture for coworking spaces. Since the future of the workspace will focus on the idea of a team, of joining the community and promoting collaboration, the solution can be a flexible and modular furniture system, which allows to easily create and quickly diverse configurations that meet different purposes in the workplace, without changing the identity of the space.

It is interesting for future research to analyse coworking spaces from other cities and countries, in order to help designers, because cultural differences have an impact on our lifestyle and consequently on the way we work. Designers must pay special attention to cultural differences when designing furniture, as they can raise different requirements, which can be reflected in functionality, ergonomics and the choice of materials and finishes used. 


\section{NOTAS}

${ }^{1}$ Inka Kojoand Suvi Nenonen, "Evolution of co-working places: drivers and possibilities," Intelligent Buildings International 9, no.3 (2014): 164-175.https://doi.org/10.1080/17508975 .2014 .987640

${ }^{2}$ OECD, Policy Responses to New Forms of Work (Paris: OECD Publishing, 2019), 5-20, https:// doi.org/10.1787/0763f1b7-en

${ }^{3}$ Anthony Giddens, "Um Mundo em Mudança" in Sociologia (Lisboa: Fundação Calouste Gulbenkian, 2001), 48-77.

${ }^{4}$ Michelle O'Brien, "Finding a home for the 'digital nomad," May, 2012, accessed March 2, 2020, http://www.michelleobrien.net/wp-content/uploads/2011/10/OBRIEN Home digital nomad.pdf ${ }^{5}$ Daciano da Costa, Design e Mal-Estar (Lisboa: Centro Português do Design, 1998), 13.

${ }^{6}$ Rudolf Pütz, "Work becomes multi-local," interview by Orgatec, Orgatec News Blog - New Visions Of Work, October 25-29, 2016, accessed November 10, 2016, http://news.orgatec. com/2016/10/work-becomes-multi-local-an-interview-with-rudolf-putz-from-vitra/

${ }^{7}$ Millennials or Generation Y are those people born in the early 1980's to the late 1990's, between Generation X and Generation Z.

${ }^{8}$ Millennials make up 65\% of the global Coworking community," Shared Space, accessed February 20, 2020, https://sharedspace.work/why-coworking-works-for-millennials/

${ }^{9}$ Kylie Roth and Nicole Mirchandani, "The rise of co-working: A growing workplace movement," Corporate Real Estate Journal 5, no.4 (July 2016): 1-5.

10 "Global Coworking Growth Study 2020," Coworking Resources, accessed July 4, 2020, https:// www.coworkingresources.org/blog/key-figures-coworking-growth

${ }^{11}$ Georgios Mouratidis, "Digital Nomadism: Travel, Remote Work and Alternative Lifestyles" (Master diss., Lund University, 2018), 7, accessed March 3, 2020, http://lup.lub.lu.se/luur/ download? func $=$ downloadFile\&recordOId $=8948916 \&$ fileOId $=8949060$

12 "5 Factors to Consider When Choosing a Coworking Space," Deskmag, accessed May 15, 2020, https://www.deskmag.com/en/coworkers/5-factors-to-find-to-choose-the-right-coworkingspace-969

13 "Factors to consider when choosing a coworking space," Open Sourced Workplace, accessed October 10, 2020, https://www.opensourcedworkplace.com/news/factors-to-consider-whenchoosing-a-coworking-space

${ }^{14}$ Elif Süyük Makakl, Ebru Yücesan and Betül Ozar, "Co-Working Space Concept in the Spatial and Urban Context: A Case Study of "Kolektif House," FSM Scholarly Studies:Journal of Humanities and Social Sciences, no.14, (2019): 301-302. https://doi.org/10.16947/fsmia.667316. ${ }^{15}$ Gilles Lipovetsky, Da Leveza. Para uma Civilização do Ligeiro (Lisboa: Edições 70, 2016), 133

${ }^{16}$ Lipovetsky, Da Leveza. Para uma Civilização do Ligeiro, 238.

${ }^{17}$ Juhani Pallasmaa, The Eyes of the Skin. Architecture and the Senses (London: Academy Group, 1996), 41.

${ }^{18}$ Steen Eiler Rasmussen, Experiencing Architecture (Cambridge, Massachusetts: MIT Press paperbackedition, 1959), 224.

${ }^{19}$ Peter Zumthor, Atmospheres: Architectural Environments. Surronding Objects (Basel: Birkhäuser, 2006), 29.

${ }^{20}$ Rex Miller, Philip Williams and Michael O'Neill, The Healthy Workplace Nudge: How Healthy People, Culture, and Buildings lead to high performance (New Jersey, United States of America: John Wiley \& Sons, 2018), 105.

${ }^{21}$ Swantje Robelski, Helena Keller, Volker Harth and Stefanie Mache, "Coworking Spaces: The Better Home Office? A Psychosocial and Health-Related Perspective on an Emerging Work Environment," International Journal of Environmental Research and Public Health (2019): 1-2. https://doi.org/10.3390/ijerph16132379 
${ }^{22}$ Nicola Gillen, Hilary Jeffery and Charlotte Hermans, "Wellbeing," in Future Office: Next Generation Workplace Design, ed. Nicola Gillen (London: Riba Publishing, 2019), 76.

${ }^{23}$ Dale Sinclair, "The changing nature of technology and work," in Future Office: Next Generation Workplace Design, ed. Nicola Gillen (London: Riba Publishing, 2019), 58.

${ }^{24}$ Nicola Gillen, "Fast forward to the Future," in Future Office: Next Generation Workplace Design, ed. Nicola Gillen (London: Riba Publishing, 2019), 171.

25 "Global Coworking Growth Study 2020," Coworking Resources, accessed July 4, 2020, https:// www.coworkingresources.org/blog/key-figures-coworking-growth

26 "2020 Future of Work Report: What the Future Holds for Coworking and Remote Work," Coworking Insights, accessed September 2, 2020, https://coworkinginsights.com/wp-content/ uploads/2020/05/CI_-_2020_Future_of_Work_Report_1.pdf

${ }^{27}$ Drew Jones, "The Future of Coworking?," OpenWork Agency, May 29, 2020, https://openwork.agency/wp-content/uploads/2020/05/The-Future-of-Coworking-White-Paper-OpenWorkAgency-May-29-2020.pdf 